\title{
Performance of different methods to estimate reference evapotranspiration in Cruz Alta - RS
}

\section{Desempenho de diferentes métodos de estimativa da evapotranspiração de referência para Cruz Alta - RS}

\begin{abstract}
Elisa de Almeida GOLLO'; Jhosefe BRUNING²; Adroaldo Dias ROBAINA ${ }^{3}$; Marcia Xavier PEITER ${ }^{4}$; Taise Cristine BUSKE 5 ; Ricardo BOSCAINI ${ }^{6}$; Silvana Antunes RODRIGUES ${ }^{6}$; Jessica Dariane PIROLI ${ }^{6}$; Pablo Eanes Cocco RODRIGUES ${ }^{6}$; Bruna Dalcin PIMENTA ${ }^{6}$

${ }^{1}$ Autor para correspondência; Doutoranda do Programa de Pós-Graduação em Engenharia Agrícola; da Universidade Federal de Santa Maria, Campus Santa Maria; Departamento de Engenharia Rural; Centro de Ciências Rurais Prédio 42, 3ํPiso, CEP 97105-900, Santa Maria -RS. elisagollo@hotmail.com

${ }^{2}$ Mestrando do Programa de Pós-Graduação em Engenharia Agrícola da Universidade Federal de Santa Maria; jhosefe.b@gmail.com

${ }^{3}$ Engenheiro Agrônomo, Dr., Professor da Universidade Federal de Santa Maria, Campus Santa Maria; diasrobaina@gmail.com

${ }^{4}$ Engenheira Agrônoma, Dra., Professora da Universidade Federal de Santa Maria, Campus Santa Maria; mpeiter@gmail.com ${ }^{5}$ Doutoranda do Programa de Pós-Graduação em Engenharia Agrícola da Universidade Federal de Santa Maria; taisecbuske@gmail.com

${ }^{6}$ Mestrandos do Programa de Pós-Graduação em Engenharia Agrícola da Universidade Federal de Santa Maria; ricardoboscaini75@gmail.com; rodrigues.silvana.a@gmail.com; jehpiroli@hotmail.com; cocco.pablo@hotmail.com; brunadpimenta@gmail.com
\end{abstract}

Recebido em: 29-05-2017; Aceito em: 02-02-2018

\begin{abstract}
The objective of this work was to evaluate the performance of different methods to estimate reference evapotranspiration (ETo) in the municipality of Cruz Alta - RS, using the Penman-Monteith method as standard. Daily meteorological data were collected from the Automatic Meteorological Station of the National Meteorological Institute (INMET), located in the municipality of Cruz Alta - RS, for a 10-year period. ETo was determined using the methods of Penman-Monteith, Priestley-Taylor, Hargreaves-Samani, Benevides-Lopes and Jensen-Haise, comparing the standard method with the other methods used for three subgroups of data: analysis of the average of 10 years of observations and periods of high and low solar radiation. In order to establish the best methods for estimating ETo, we used: linear regression analysis, root mean square error (RMSE), mean absolute error (MAE), agreement index (d), and performance index (c), with classes established by Camargo and Sentelhas. Among the methods evaluated for the climatic conditions of Cruz Alta - RS, the Priestley-Taylor method is the one that presents the best performance in ETo estimation, followed by the Hargreaves-Samani method, which can be used in daily and annual determinations, and in periods of high solar radiation. Due to the poor performance presented by the Jensen-Haise method, its use is not recommended.
\end{abstract}

Additional keywords: empirical equations; Penman-Monteith; climate variables.

\section{Resumo}

O objetivo deste trabalho foi avaliar o desempenho de diferentes métodos de estimativa da evapotranspiração de referência (ETo) para o município de Cruz Alta - RS, utilizando-se como padrão do método de Penman-Monteith. Os elementos meteorológicos diários foram coletados da Estação Meteorológica Automática do Instituto Nacional de Meteorologia (INMET), localizada no município de Cruz Alta - RS, para um período total de 10 anos. A ETo foi determinada a partir dos métodos de Penman-Monteith, Priestley-Taylor, Hargreaves-Samani, BenevidesLopes e Jensen-Haise, realizando-se comparações entre o método padrão e os demais métodos utilizados para três subgrupos de dados, que foram: análise da média dos 10 anos de observações e períodos de alta e baixa radiação solar. A fim de estabelecer os melhores métodos para a estimativa da ETo, utilizaram-se: análise de regressão linear, raiz do quadrado médio do erro (RQME), erro absoluto médio (EAM), índice de concordância (d) e índice de desempenho (c), com classes estabelecidas por Camargo e Sentelhas. Dentre os métodos avaliados para as condições climáticas de Cruz Alta - RS, o método de Priestley-Taylor é o que apresenta o melhor desempenho na estimativa da ETo, seguido pelo método de Hargreaves-Samani, que pode ser utilizado em determinações anuais diárias e em períodos de alta radiação solar. Devido ao baixo desempenho apresentado pelo método de Jensen-Haise, não é indicada sua utilização.

Palavras-chave adicionais: equações empíricas; Penman-Monteith; variáveis climatológicas. 


\section{Introduction}

The municipality of Cruz Alta has the highest concentration of central pivots in the state of Rio Grande do Sul, with a total of 129 pivots in an area of approximately 9 thousand hectares, according to Martins et al. (2016). The same authors also point out that among the municipalities with the largest relative areas occupied by central pivots in the state, Cruz Alta occupies second place, with $11.74 \%$ of the total area.

In Rio Grande do Sul, irrigation is used mainly during the summer, where there is irregular distribution of rainfall, the main factor conditioning the variability of agricultural production over the years due to the occurrence of water deficits (Bergamaschi et al., 2007). One of the main parameters used to determine the water requirement of crops is evapotranspiration (Morais et al., 2015). Its correct obtention is of paramount importance for a proper irrigation management, since it represents the amount of soil water to be replenished for the plants, according to the climatic and soil water conditions in the region (Tagliaferre et al., 2010)

The reference evapotranspiration (ETo) can be obtained directly - through the estimation of the soil water balance, using lysimeters -, or indirectly, through evaporimeters or through the use of physical-mathematical models of estimation (Alves Sobrinho et al., 2011; Carvalho et al., 2015; Tanaka et al., 2016). Among the existing models, the Penman-Monteith method, considered as standard by FAO (Allen et al., 1998), besides obtaining a better precision in the estimates, is the model that best represents the physical and physiological factors involved in ETo (Carvalho et al., 2015).

Notwithstanding, this method requires the knowledge of a large number of meteorological variables for its application, which are not always available (Martí et al., 2015; Palaretti et al., 2014). For this reason, the use of simplified models is a potential alternative to estimate ETo when the available data are lim- ited (Alencar et al., 2015).

For the correct use of simplified models in substitution to the standard method of PenmanMonteith, local and regional calibrations, in addition to statistical model performance evaluations, are important for evaluating errors in ETo estimates and guiding the choice of methods that best suit the availability of local meteorological data and the level of accuracy demanded (Tagliaferre et al., 2010; Carvalho et al., 2011; Souza et al., 2011; Carvalho et al., 2015).

In view of the above, this work aimed to evaluate the performance of different methods to estimate reference evapotranspiration (ETo) in the city of Cruz Alta - RS, using the Penman-Monteith method as standard.

\section{Material and methods}

The city of Cruz Alta, in the state of Rio Grande do Sul, is located at $28^{\circ} 38^{\prime} 19^{\prime \prime}$ South and $53^{\circ}$ 36 ' 23" West, with an average altitude of 452 meters from sea level. The climate of the region is characterized, according to Köppen classification, as subtropical humid (Cfa), without dry season, with mean temperature of the hottest month above $18.5{ }^{\circ} \mathrm{C}$ and mean annual rainfall of $1,630 \mathrm{~mm}$ (Alvares et al., 2013).

For this work, the following daily meteorological data were used: mean, maximum, and minimum air temperature $\left({ }^{\circ} \mathrm{C}\right)$, mean relative humidity $(\%)$; mean wind speed at $2 \mathrm{~m}$ high $\left(\mathrm{m} \mathrm{s}^{-1}\right)$, atmospheric pressure $(\mathrm{hPa})$, insolation $(\mathrm{h})$, and solar radiation (MJ $\mathrm{m}^{-2}$ day $^{-1}$ ). These data were collected from the Automatic Meteorological Station of the National Institute of Meteorology (INMET), located in the city of Cruz Alta - RS, for the period between January 1, 2005 and December 31, 2014, totaling 10 years and 3652 observations (Table 1). The behavior of the main meteorological variables used can be observed in Figure 1.

Table 1 - Annual averages and the total period of observations of meteorological elements used to estimate ETo.

\begin{tabular}{lcccccccc}
\hline Year & $\begin{array}{c}\mathrm{Tmax} \\
\left({ }^{\circ} \mathrm{C}\right)\end{array}$ & $\mathrm{Tmin}\left({ }^{\circ} \mathrm{C}\right)$ & $\mathrm{Tm}\left({ }^{\circ} \mathrm{C}\right)$ & $\mathrm{RH}(\%)$ & $\begin{array}{c}\mathrm{WS} \\
\left(\mathrm{m} \mathrm{s}^{-1}\right)\end{array}$ & $\begin{array}{c}\mathrm{AP} \\
(\mathrm{hPa})\end{array}$ & $\begin{array}{c}\text { Insolation } \\
(\mathrm{h})\end{array}$ & $\begin{array}{c}\text { SR } \\
\left(\mathrm{MJ} \mathrm{m}^{-2} \text { day }^{-1}\right)\end{array}$ \\
\hline 2005 & 25.29 & 14.23 & 19.00 & 71.87 & 1.93 & 1006.50 & 6.95 & 17.69 \\
2006 & 25.83 & 14.21 & 19.21 & 71.64 & 1.86 & 1007.00 & 7.22 & 17.96 \\
2007 & 25.17 & 14.07 & 18.85 & 73.73 & 1.87 & 1006.60 & 6.53 & 17.07 \\
2008 & 25.26 & 13.73 & 18.65 & 81.45 & 1.94 & 1006.80 & 7.25 & 18.06 \\
2009 & 25.18 & 13.95 & 18.64 & 78.50 & 2.10 & 1006.60 & 6.58 & 17.06 \\
2010 & 24.73 & 13.93 & 18.52 & 74.86 & 2.23 & 1006.40 & 6.50 & 17.05 \\
2011 & 24.90 & 13.87 & 18.52 & 76.17 & 2.07 & 1006.50 & 6.96 & 17.68 \\
2012 & 26.14 & 14.56 & 19.48 & 75.05 & 2.08 & 1006.60 & 7.34 & 18.04 \\
2013 & 24.62 & 13.42 & 18.24 & 87.11 & 2.11 & 1006.60 & 7.21 & 17.94 \\
2014 & 25.48 & 14.95 & 19.35 & 90.98 & 2.19 & 1006.90 & 6.83 & 17.44 \\
\hline Mean & 25.26 & 14.09 & 18.85 & 78.14 & 2.04 & 1006.65 & 6.94 & 17.60 \\
\hline
\end{tabular}

Tmax: Maximum air temperature; Tmin: Minimum air temperature; Tm: Mean air temperature; RH: Air relative humidity; WS: wind speed; AP: atmospheric pressure; SR: solar radiation 


\section{A}

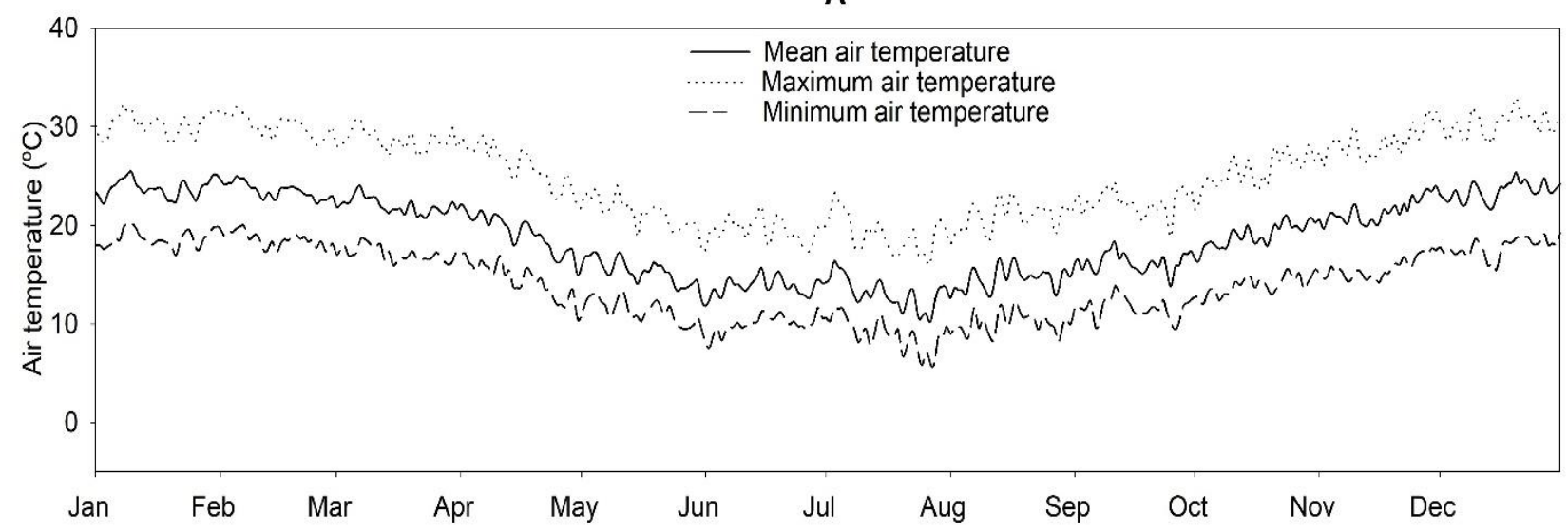

B

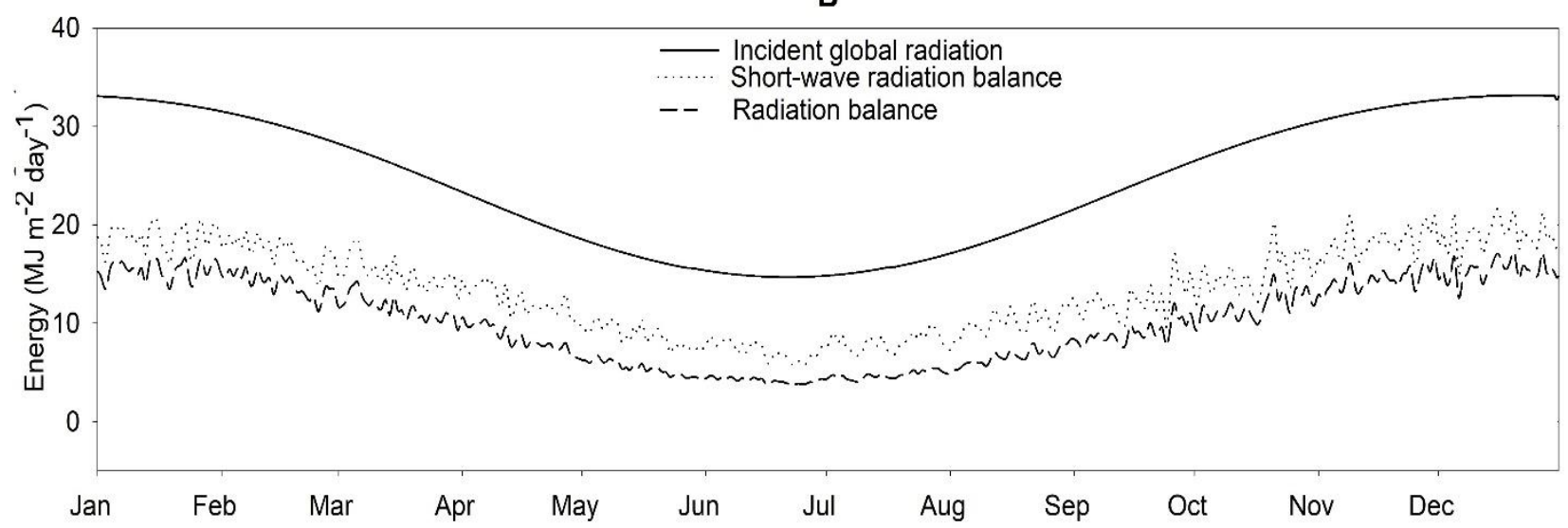

Figure 1 - Average of the mean, maximum and minimum air temperatures $(A)$, incident global radiation, short-wave radiation balance and radiation balance (B) for the period from 2005 to 2014 . * The short-wave radiation balance $\left(\mathrm{K}^{*}\right)$ and the net surface radiation $(\mathrm{Rn})$ were calculated according to Allen et al. (1998).

After collecting and tabulating the mean daily data, ETo was determined for the mentioned period from the following methods: Penman-Monteith, Priestley-Taylor, Hargreaves-Samani, Benevides-Lopes, and Jensen-Haise. Using the Penman-Monteith

method as standard, comparisons were made between this method and the aforementioned ones. The meteorological variables involved in the ETo estimation equation for each method used are shown in Table 2.

Table 2 - Meteorological elements used to estimate ETo for each method used.

\begin{tabular}{ll}
\hline Methods of estimating of evapotranspiration & Meteorological elements \\
\hline Penman-Monteith & $\mathrm{Rn} ; \mathrm{G} ; \mathrm{Tm} ; \mathrm{u}_{2} ; \mathrm{e}_{\mathrm{s}} ; \mathrm{e}_{\mathrm{a}} ; \Delta ; \mathrm{Y}$ \\
Priestley-Taylor & $\mathrm{Rn} ; \mathrm{G} ; \Delta ; \mathrm{Y} ; \lambda$ \\
Hargreaves-Samani & $\mathrm{Ra} ; \mathrm{Tmax}$ Tmin; Tm \\
Benevides-Lopes & $\mathrm{Tm} ; \mathrm{RH}$ \\
Jensen-Haise & $\mathrm{Ra} ; \mathrm{Tm}$ \\
\hline
\end{tabular}

$\mathrm{Rn}=$ net surface radiation $\left(\mathrm{MJ} \mathrm{m}^{-2} \mathrm{~d}^{-1}\right) ; \mathrm{G}=$ density of heat flux in the soil $\left(\mathrm{MJ} \mathrm{m}^{-2}\right.$ day $\left.^{-1}\right) ; \mathrm{T}=$ air temperature at $2 \mathrm{~m}$ high $\left({ }^{\circ} \mathrm{C}\right)$; $\mathrm{U}_{2}=$ wind speed at $2 \mathrm{~m}$ high $\left(\mathrm{m} \mathrm{s}^{-1}\right) ; \mathrm{e}_{\mathrm{s}}=$ saturation vapor pressure $(\mathrm{kPa}) ; \mathrm{e}_{\mathrm{a}}=$ partial vapor pressure $(\mathrm{kPa}) ; \Delta=$ slope of the saturation vapor pressure curve $\left(\mathrm{kPa}^{\circ} \mathrm{C}^{-1}\right) ; \mathrm{\gamma}=$ psychrometric coefficient $\left(\mathrm{kPa}^{\circ} \mathrm{C}^{-1}\right) ; \lambda=$ latent heat of vaporization $\left(\mathrm{MJ} \mathrm{kg}^{-1}\right)$; $\operatorname{Tmax}=$ maximum temperature of the day $\left({ }^{\circ} \mathrm{C}\right) ; \mathrm{Tmin}=$ minimum temperature of the day $\left({ }^{\circ} \mathrm{C}\right) ; \mathrm{Tm}=$ mean temperature of the $\left({ }^{\circ} \mathrm{C}\right) ; \mathrm{Ra}=$ extraterrestrial radiation $\left(\mathrm{MJ} \mathrm{m}^{-2}\right.$ day $\left.^{-1}\right) ; \mathrm{Rs}=$ daily average global solar radiation $\left(\mathrm{MJ} \mathrm{m}^{-2}\right.$ day $\left.^{-1}\right)$.

To perform the comparisons, in order to identify possible variations in the ETo estimation for each method in daily scales and evapotranspiration conditions, the meteorological data were divided into three 
subgroups: analysis of the average of 10 years of observations, analysis of the days with a solar radiation balance higher than the mean radiation balance (Rn > $10.13 \mathrm{MJ} \mathrm{m}^{-2}$ day $^{-1}$ ), and days with a solar radiation balance lower than or equal to the mean radiation balance $\left(\mathrm{Rn} \leq 10.13 \mathrm{MJ} \mathrm{m}^{-2}\right.$ day $\left.^{-1}\right)$. For the last subgroup, the radiation balance was calculated according to the methodology proposed by Allen et al. (1998), and the mean daily radiation balance was calculated, being $10.13 \mathrm{MJ} \mathrm{m}^{-2}$ day $^{-1}$. Subsequently, the data were classified as a function of the mean value, totaling 1667 observations for days with $\mathrm{Rn}$ above the mean, and 1985 observations for days with $\mathrm{Rn}$ equal to or below the mean.

The linear regression analysis, which used the model $Y_{i}=a+b \hat{Y} i$ to compare the ETo values obtained by the Penman-Monteith method (Yi) and the other methods used ( $\hat{\mathrm{Y}} \mathrm{i})$, was employed to establish the methods that better estimate ETo in relation to the standard method, for the three subgroups. From the generated equations, the linear and angular coefficients, coefficients "a" and "b", respectively, and the coefficient of determination $\left(R^{2}\right)$ were analyzed. The methods considered to show the best ETo estimation were those with regression coefficient "a" closer to zero, coefficient "b" closer to the unit, and coefficient of determination closer to one.

In addition to the abovementioned criteria, for the establishment of the best ETo estimation methods, the following were also calculated: root mean square error (RMSE), mean absolute error (EAM), and some indicators of statistical performance among the methods, which were: agreement index (d), which determines the degree of distance from the estimated values in relation to the observed values (Willmott, 1981); and the performance index (c) of Camargo and Sentelhas (1997), according to the classification indicated in Table 3.

Table 3 - Criteria for the classification of the performance of the methods of estimation of the reference evapotranspiration by the $c$ index.

\begin{tabular}{ll}
\hline Values of $c$ index & Performance \\
\hline$>0.85$ & Great \\
0.76 to 0.85 & Very good \\
0.66 to 0.75 & Good \\
0.51 to 0.65 & Regular \\
0.41 to 0.50 & Poor \\
$<0.41$ & Very Poor \\
\hline
\end{tabular}

Adapted from Camargo \& Sentelhas (1997).

\section{Results and discussion}

In the comparison analysis between the different ETo estimation methods and the Penman-Monteith method for the 10-year period of observations (Table 4), it was verified from the coefficient of determination $\left(\mathrm{R}^{2}\right)$ that the methods of Priestley-Taylor, Hargreaves-Samani, and Benevides-Lopes obtained good estimation accuracy, with coefficients of determination of $0.98,0.98$, and 0.93 , respectively. On the other hand, the Jensen-Haise method presented less precision than the others, with $\mathrm{R}^{2}$ of 0.73 . Morais et al. (2015) found similar precision for the JensenHaise method, with coefficients of determination of 0.75 for Petrolina-PE.

Analyzing the values of coefficients "a" and "b" generated by the regression equations found for the different methods and the data dispersion observed in Figure 2, it was found that the methods of PriestleyTaylor, Hargreaves-Samani, and Jensen-Haise tended to overestimate the data by $13 \%, 21 \%$, and $141 \%$, respectively, while the Benevides-Lopes method showed a tendency of $14 \%$ underestimation.

Table 4 - Means of ETo, regression analysis results ( $a, b$ and $R^{2}$ ), root of error mean squared (REMS), mean absolute error (MAE), concordance index (d), performance index (c) and performance for the period from January 1, 2005 to December 31, 2014.

\begin{tabular}{cccccccccc}
\hline \multirow{2}{*}{$\begin{array}{c}\text { ETo } \\
\text { methods }\end{array}$} & $\begin{array}{c}\text { ETo average } \\
\left(\mathrm{mm} \mathrm{day}^{-1}\right)\end{array}$ & \multicolumn{10}{c}{ Performance indices } \\
\cline { 3 - 10 } & & $\mathrm{a}$ & $\mathrm{b}$ & $\mathrm{R}^{2}$ & REMS & MAE & $\mathrm{d}$ & $\mathrm{c}$ & Performance \\
\hline P-M & 3.160 & - & - & - & - & - & - & - & - \\
P-T & 3.591 & 0.213 & 0.821 & 0.986 & 0.549 & 0.455 & 0.968 & 0.961 & Great \\
H-S & 3.830 & -0.263 & 0.894 & 0.981 & 0.714 & 0.669 & 0.942 & 0.933 & Great \\
B-L & 2.703 & 0.289 & 1.063 & 0.932 & 0.586 & 0.492 & 0.951 & 0.918 & Great \\
J-H & 7.625 & -0.082 & 0.425 & 0.731 & 4.841 & 4.465 & 0.457 & 0.390 & Very poor \\
\hline
\end{tabular}

P-M = Penman-Monteith, P-T = Priestley-Taylor, H-S = Hargreaves-Samani, B-L = Benevides-Lopes, J-H = Jense-Haise 
A

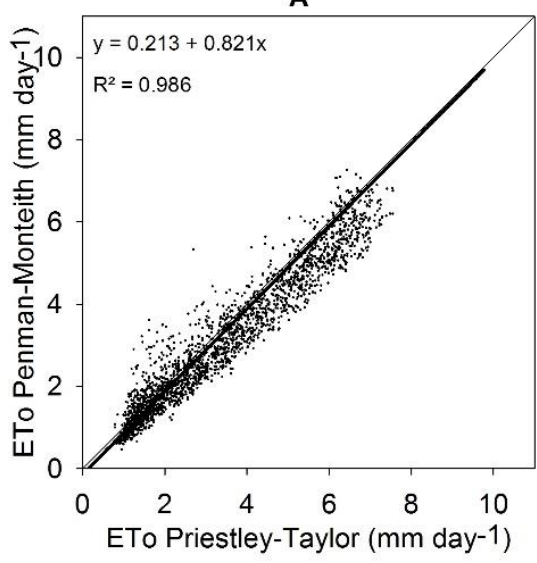

C

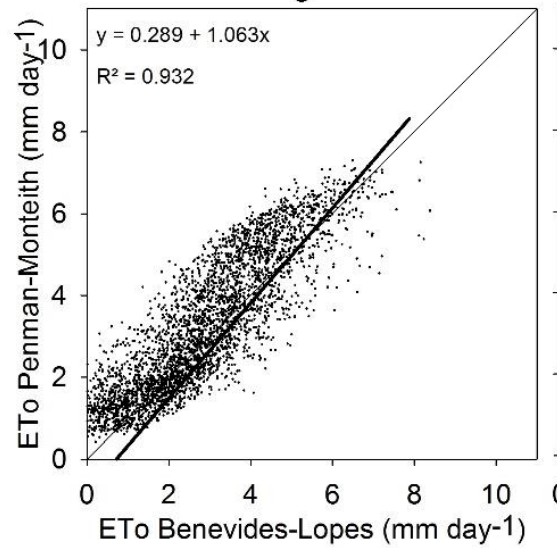

B

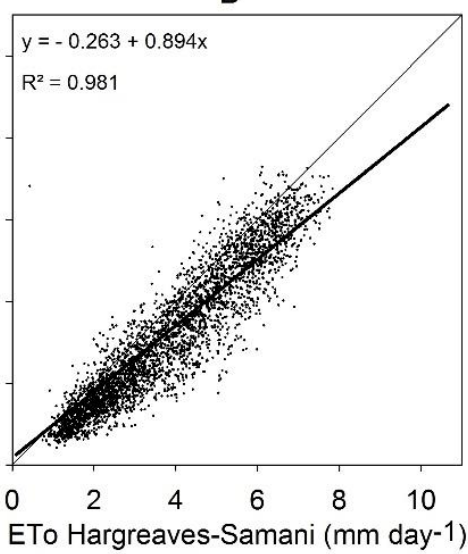

D

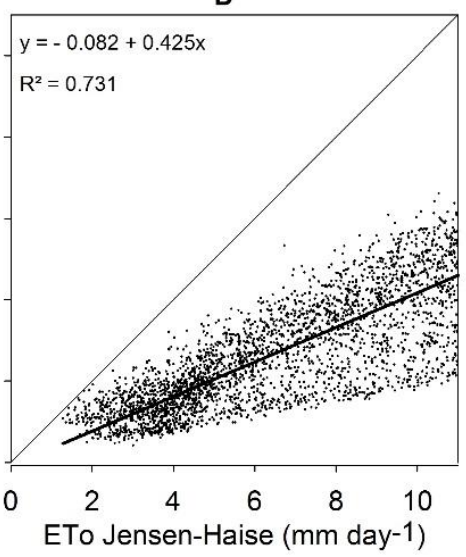

Figure 2 - Graphical representation of the daily reference evapotranspiration (ETo) estimate obtained by the standard method, compared to the values obtained by the other methods for the period from January 1, 2005 to December 31, 2014.

Disagreeing with the present study, for the methods of Priestley-Taylor and Hargreaves-Samani, Guedes Filho et al. (2011) and Silva et al. (2012) observed a tendency of ETo underestimation in daily data for the city of Areia - PB and for the northern region of Recife - PE, respectively. On the other hand, Tagliaferre et al. (2010) observed, for Eunápolia - BA, a behavior similar to that observed in this study, where the Hargreaves-Samani method showed a tendency of $23 \%$ overestimation of ETo data. Vallory et al. (2016) also observed a tendency of overestimation of ETo data for the state of Rio de Janeiro, using the PriestleyTaylor and Hargreaves-Samani methods.

Regarding performance indices, the values obtained for root mean square error (RMSE), mean absolute error (MAE), agreement index (d), and performance index (c) indicated the Priestley-Taylor method to be the best, followed by the methods of Hargreaves-Samani and Benevides-Lopes, the three of them being classified as "Great", and the JensenHaise method classified as "Poor". Tagliaferre et al. (2010), in Eunápolis - BA and Uberlândia - MG, and Sanches et al. (2015), in the northern region of Brazil, also found the Priestley-Taylor method to be of better performance among other methods used.

Corroborating with this study, similar results were observed by Silva et al. (2014) when comparing ETo estimation methods for Piracicaba - SP, obtaining a great performance of the Hargreaves-Samani method in relation to the Penman-Monteith method, with a coefficient of determination of 0.957 .

Tanaka et al. (2016) reported, in a study carried out in the state of Mato Grosso, that the JensenHaise method presented, as a whole, the worst statistical indicators in the estimation of ETo in daily scale, compared to the other methods studied. Moreover, the same authors, when observing the data dispersion around the $1: 1$ line regarding the ETo estimated by Penman-Monteith and by other methods, found that the Jensen-Haise method presents one of the worst correlations for ETo estimation. The same behavior verified by the aforementioned authors for the JensenHaise data dispersion was observed in the present work.

In order to evaluate periods of high and low solar radiation, the data were classified in days with a solar radiation balance higher than and days with a solar radiation balance lower than or equal to the mean radiation balance, being then analyzed. This differentiated analysis was carried out with the objective of simulating, with the data of high radiation balance, periods of high evapotranspiration demand, and with the data 
of low radiation balance, periods of lower demand, such as summer and winter seasons in Rio Grande do Sul. This is because during the period of high evapotranspiration demand, the crops need higher water consumption, thus being the most important period for obtaining precision in ETo estimation (Alencar et al., 2011a).

For the conditions of days with solar radiation balance higher than and days with radiation balance less than or equal to the mean balance (Table 5 and Figure 3), the methods of Priestley-Taylor, Hargreaves-
Samani, and Jensen-Haise presented coefficients of determination of $0.78,0.67$, and 0.51 , respectively, and decreased performance in relation to the overall mean, being classified as "Good", "Good", and "Very Poor", respectively, for days with solar radiation balance higher than the mean value. On the other hand, the Benevides-Lopes method presented a coefficient of determination of 0.64 , data underestimation tendency of $17 \%$, and "Regular" performance, different from what was observed for this method in the general analysis, in which it was classified as "Great".

Table 5 - Means of ETo, regression analysis results ( $a, b$ and $R^{2}$ ), root of error mean squared (REMS), mean absolute error (MAE), concordance index (d), performance index (c) and performance for the condition of days with a higher than average radiation balance; and days with radiation balance less than or equal to the general average of the radiation balance for the period January 1, 2005 to December 31, 2014.

\begin{tabular}{|c|c|c|c|c|c|c|c|c|c|}
\hline \multirow{2}{*}{$\begin{array}{c}\text { ETo } \\
\text { methods }\end{array}$} & \multirow{2}{*}{$\begin{array}{l}\text { ETo average } \\
\left(\mathrm{mm}_{\text {day }}{ }^{-1}\right)\end{array}$} & \multicolumn{8}{|c|}{ Performance indices } \\
\hline & & $a$ & $\mathrm{~b}$ & $\mathrm{R}^{2}$ & REMS & MAE & d & C & Performance \\
\hline & & \multicolumn{8}{|c|}{$\begin{array}{l}\text { Days with solar radiation balance greater than the general average } \\
\qquad\left(\mathrm{Rn}>10.13 \mathrm{MJ} \mathrm{m}^{-2} \text { day }^{-1}\right)\end{array}$} \\
\hline P-M & 4.673 & 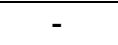 & 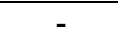 & & & & & - & - \\
\hline P-T & 5.391 & 0.029 & 0.861 & 0.782 & 0.887 & 0.763 & 0.846 & 0.748 & Goc \\
\hline $\mathrm{H}-\mathrm{S}$ & 5.340 & 0.236 & 0.830 & 0.677 & 0.918 & 0.752 & 0.826 & 0.680 & Good \\
\hline B-L & 3.896 & 2.108 & 0.658 & 0.642 & 1.099 & 0.917 & 0.800 & 0.641 & Regular \\
\hline \multirow[t]{2}{*}{$\mathrm{J}-\mathrm{H}$} & 10.326 & 0.865 & 0.368 & 0.511 & 5.850 & 5.653 & 0.279 & 0.200 & Very poor \\
\hline & \multicolumn{9}{|c|}{$\begin{array}{l}\text { Days with solar radiation balance less than or equal to average } \\
\qquad\left(\mathrm{Rn} \leq 10.13 \mathrm{MJ} \mathrm{m}^{-2} \text { day }^{-1}\right)\end{array}$} \\
\hline P-M & 1.879 & - & - & & & - & & & - \\
\hline P-T & 2.077 & 0.118 & 0.847 & 0.704 & 0.473 & 0.385 & 0.898 & 0.753 & Good \\
\hline $\mathrm{H}-\mathrm{S}$ & 2.552 & 0.257 & 0.635 & 0.604 & $0.8 s$ & & 0.750 & & Regular \\
\hline B-L & 1.693 & 1.090 & 0.465 & 0.637 & 0.855 & 0.660 & 0.818 & 0.652 & Regular \\
\hline $\mathrm{J}-\mathrm{H}$ & 5.336 & 0.864 & 0.190 & 0.354 & 4.000 & 3.453 & 0.290 & 0.173 & Very poor \\
\hline
\end{tabular}

$\mathrm{P}-\mathrm{M}=$ Penman-Monteith, P-T = Priestley-Taylor, H-S = Hargreaves-Samani, B-L = Benevides-Lopes, J-H = Jense-Haise
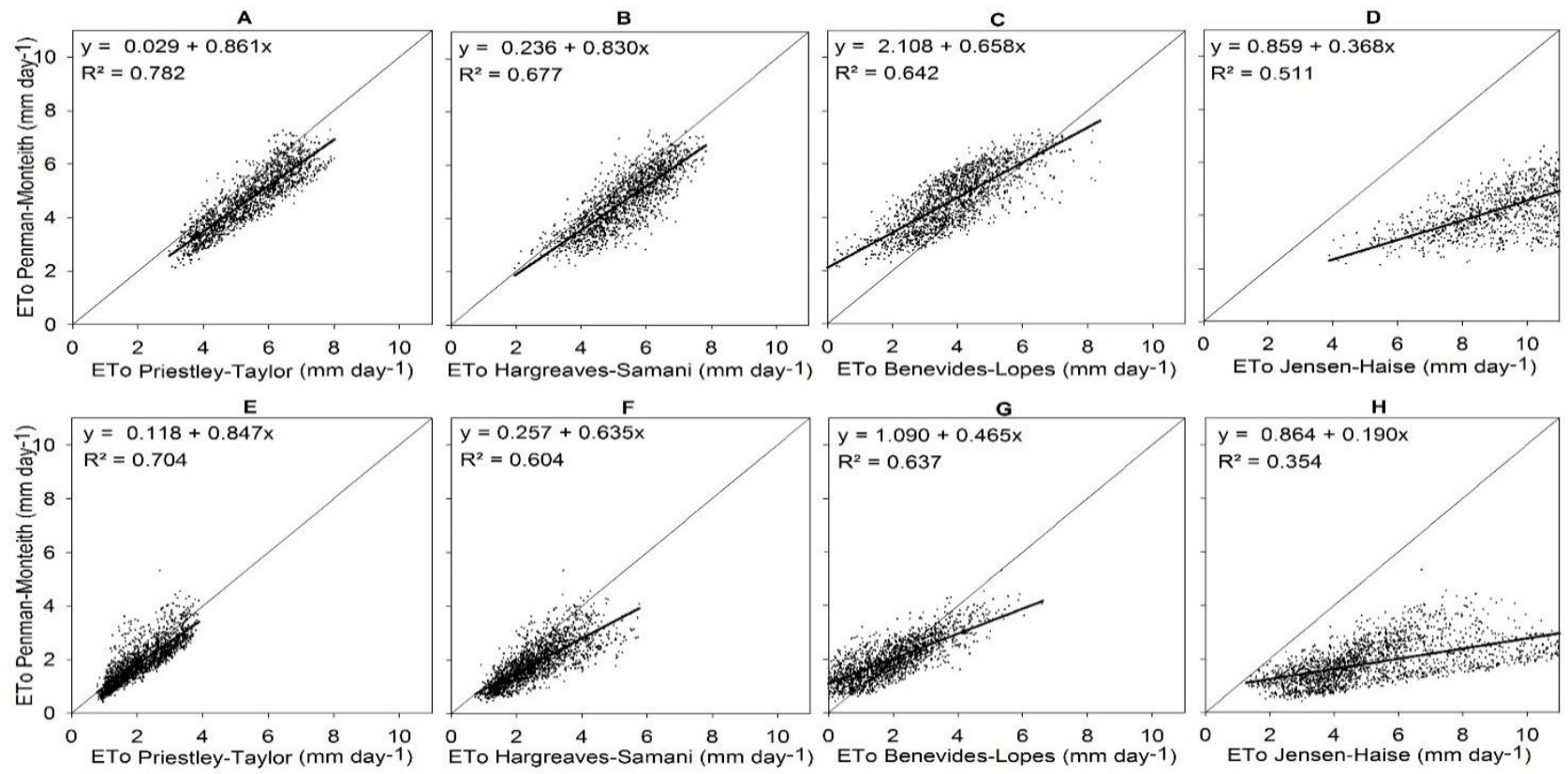

Figure 3 - Graphical representation of the daily reference evapotranspiration (ETo) estimate obtained by the standard method compared to the values obtained by other methods for the conditions of days with a higher than average radiation balance $\left(\mathrm{Rn}>10.13 \mathrm{MJ} \mathrm{m}^{-2}\right.$ day $\left.^{-1}\right)(\mathrm{A}, \mathrm{B}, \mathrm{C}, \mathrm{D})$; and days with radiation balance less than or equal to the general average of the radiation balance $\left(R n \leq 10,13 \mathrm{MJ} \mathrm{m}^{-2}\right.$ day $\left.^{-1}\right)(E, F, G, H)$. 
Regarding the high radiation condition, the Priestley-Taylor and Hargreaves-Samani methods presented satisfactory performance for ETo estimation, being classified as "Good". Alencar et al. (2011b), in a study carried out for northern Minas Gerais, presented similar results regarding the abovementioned methods for high evaporative demand, presenting an agreement index classified as "Great" for Priestley-Taylor, and "Good" for Hargreaves-Samani.

For the aforementioned condition, the Benevides-Lopes method obtained a performance classified as "Regular". The Jensen-Haise method obtained a "Very Poor" performance and its use is not recommended. The said method, according to Pereira et al. (1997), was developed for arid and semi-arid regions, being used in irrigated areas, and estimated for periods of 5 to 10 days, conditions different from those developed in the present study. In addition, Fanaya Júnior et al. (2012) reported that due to the simplicity of the Jensen-Haise equation, it does not allow its use in large ranges of climatological conditions, thus justifying the low performance found for the method in this work. The performance of the tested methods indicates that it is preferable to use the Priestley-Taylor and Hargreaves-Samani methods to estimate ETo under high radiation.

For the comparison analysis of the methods for days with a solar radiation balance lower than or equal to the mean value, an ETo overestimation tendency of $10 \%, 35 \%$, and $183 \%$ was observed with the methods of Priestley-Taylor, Hargreaves-Samani, and JensenHaise, respectively, and a tendency of $10 \%$ underestimation was obtained with the Benevides-Lopes method. For this condition, the best performing method was the Priestley-Taylor, which was classified as "Good", followed by the methods of Benevides-Lopes, Hargreaves-Samani, and Jensen-Haise, which were classified as "Regular", "Regular", and "Very Poor", respectively.

For the low solar radiation condition, the Jensen-Haise method should not be applied, since it presented an unsatisfactory performance. The Priestley-Taylor method is best suited for this condition, followed by the methods of Hargreaves-Samani and Benevides-Lopes. Alencar et al. (2011a) found similar results for the Hargreaves-Samani method, with the worst performance in the months when the lowest insolation values occur in the Uberaba-MG region.

The Benevides-Lopes method, both for days with a radiation balance higher than and days with a radiation balance lower than the mean for the period, presented performance index (c) values similar to those found by Rigoni et al. (2013) in a study carried out in Aquidauana - MS, being classified as "Regular".

In the conditions evaluated in this work, it was observed that the Priestley-Taylor method obtained the best performance in relation to the other methods in the overall analysis of the 10-year period, with high and low solar radiation, being than recommended for ETo estimation in the studied region. The best performance of the Priestley-Taylor method is related to the fact that it uses, as well as the Penman-Monteith method, the radiation balance to estimate ETo, and also a greater number of meteorological variables, giving it greater accuracy. However, the application of this method is restricted to sites that have available radiation data in meteorological stations, the main limitation found for not using the standard method of Penman-Monteith and searching for alternative methods (Silva et al., 2011).

Regarding the studied methods that do not use the radiation balance to estimate ETo, the Hargreaves-Samani and Benevides-Lopes can be recommended for overall means of historical series, since they presented performances classified as "Great". Furthermore, these methods have the advantage of greater simplicity and ease of application in relation to the Priestley-Taylor and Penman-Monteith methods, since radiation data are not required. Bezerra et al. (2014) and Borges Júnior et al. (2012) also observed a better performance of the HargreavesSamani and Benevides-Lopes methods among those used to determine the air temperature.

Notwithstanding, for conditions of days with a radiation balance higher than and days with a radiation balance lower than or equal to the mean value, these behaviors were not repeated. The Hargreaves-Samani method can be indicated for high radiation conditions, since it presented a performance classified as "Good", but for low radiation conditions, it should not be used due to its behavior classified as "Regular". However, regarding both the Benevides-Lopes and JensenHaise methods, which presented "Regular" and "Very Poor" performance, respectively, for both conditions, their use should be discouraged.

\section{Conclusions}

For the climatic conditions of Cruz Alta - RS, the Priestley-Taylor method presents the best performance in ETo estimation.

The Hargreaves-Samani method can be used to estimate ETo in Cruz Alta - RS, in daily and annual determinations, and in periods of high solar radiation.

Due to the poor performance achieved by the Jensen-Haise method, its use is not recommended for Cruz Alta-RS.

\section{References}

Alencar LP, Delgado RC, Almeida TS, Wanderley HS (2011a) Comparação de diferentes métodos de estimativa diária da evapotranspiração de referência para a região de Uberaba. Revista Brasileira de Ciências Agrárias 6(2):337-343. doi:10.5039/agraria.v6i2a1124.

Alencar LP, Sediyama GC, Wanderley HS, Almeida TS, Delgado RC (2011b) Avaliação de métodos de estimativa da evapotranspiração de referência para três localidades no norte de Minas Gerais. Revista Engenharia na Agricultura 19(5):437-449. doi:10.13083/reveng.v19i5.260. 
Alencar LP, Sediyama GC, Mantovanie C (2015) Estimativa da evapotranspiração de referência (ETo padrão FAO), para Minas Gerais, na ausência de alguns dados climáticos. Revista Engenharia Agrícola 35(1):39-50. doi: http://dx.doi.org/10.1590/1809-4430Eng.Agric.v35n1p39-50/2015.

Allen RG, Pereira LS, Raes D, Smith M (1998) Crop Evapotranspiration: Guidelines for computing crop water requirements. Rome, FAO. 301p.

Alvares Ca, Stape Jl, Sentelhas, PC, Gonçalves JLM, Sparovek G (2013) Köppen's climate classification map for Brazil. Meteorologische Zeitschrift 22:711-728. doi: https://doi.org/10.1127/0941-2948/2013/0507

Alves Sobrinho T, Rodrigues DBB, Oliveira PTS, Rebucci LCS, Pertussatt CA (2011) Estimativa da evapotranspiração de referência através de redes neurais artificiais. Revista Brasileira de Meteorologia $26: 197-203$.

Bergamaschi $\mathrm{H}$, Wheeler TR, Challinor JA, Comiran $\mathrm{F}$, Heckler BMM (2007) Maize yield and rainfall on different spatial and temporal scales in Southern Brazil. Pesquisa Agropecuária Brasileira 42(5):603-613. doi: http://dx.doi.org/10.1590/S0100-204X2007000500001.

Bezerra JM, Moura GBA, Silva EFF, Lopes PMO, Silva BB (2014) Estimativa da evapotranspiração de referência diária para Mossoró (RN, Brasil). Revista Caatinga 27(3):211 - 220.

Borges Júnior JCF, Anjos RJ, Silva TJA, Lima JRS, Andrade CLT (2012) Métodos de estimativa da evapotranspiração de referência diária para a microrregião de Garanhuns, PE. Revista Brasileira de Engenharia Agrícola e Ambiental 16(4):380-390.

Camargo AP, Sentelhas PC (1997) Avaliação do desempenho de diferentes métodos de estimativa da evapotranspiração potencial no estado de São Paulo, Brasil. Revista Brasileira de Agrometeorologia 5(1):8997.

Carvalho DF, Rocha HS, Bonomo R, Souza AP (2015) Estimativa da evapotranspiração de referência a partir de dados meteorológicos limitados. Pesquisa Agropecuária Brasileira 50:1-11. doi: 10.1590/S0100204X2015000100001.

Carvalho LG, Rios GFA, Miranda WL, Neto PC (2011) Evapotranspiração de referência: uma abordagem atual de diferentes métodos de estimativa. Pesquisa Agropecuária Tropical 41:456-465. doi: 10.5216/pat.v41i3.12760.

Fanaya Júnior ED, da Silva Lopes A, de Oliveira GQ, Jung LH (2012) Métodos empíricos para estimativa da evapotranspiração de referência para Aquidauana MS. Irriga, 17(4): 418-434.

http://dx.doi.org/10.15809/irriga.2012v17n4p418.
Guedes Filho DH, Santos Júnior JA, Costa Filho JF, Francisco PRM, Campos VB (2011) Estimativa da evapotranspiração de referência para a cidade de Areia, Paraíba. Revista Brasileira de Agricultura Irrigada 5(1):37-47.

Martí P, Zarzo M, Vanderlinden K, Girona J (2015) Parametric expressions for the adjusted Hargreaves coefficient in Eastern Spain. Journal of Hydrology 529(1):1713-1724.

doi: https://doi.org/10.1016/j.jhydrol.2015.07.054.

Martins JD, Bohrz IS, Tura EF, Fredrich M, Veronez RP, Kunz GA (2016) Levantamento da área irrigada por pivô central no estado do Rio Grande do Sul. Revista Irriga 21(2):300-311. doi: http://dx.doi.org/10.15809/irriga.2016v21n2p300-311.

Morais JEF, Silva TGF, Souza LSB, Moura MSB, Silva Diniz WJ, Souza CAA (2015) Avaliação do método de Penman Monteith FAO 56 com dados faltosos e de métodos alternativos na estimativa da evapotranspiração de referência no Submédio Vale do São Francisco. Revista Brasileira de Geografia Física 8(6):1644-1660.

Palaretti LF, Mantovani EC, Sediyama GC (2014) Análise da sensibilidade dos componentes da equação de Hargreaves-Samani para a região de Bebedouro-SP. Revista Brasileira de Meteorologia 29(2):299-306. doi: http://dx.doi.org/10.1590/S0102-77862014000200012.

Pereira AR, Villa Nova NA, Sediyama GC (1997) Evapotranspiração. FEALQ. 183 p.

Rigoni ER, Oliveira GQO, Biscaro GA, Queiróz MVBM, Lopes AS (2013) Desempenho sazonal da evapotranspiração de referência em Aquidauana, MS. Revista Engenharia na Agricultura 21(6):547-562.

Sanches FM, Ximenes AR, Coradi PC, Roque CG, Cunha FF (2015) Estimativa da evapotranspiração de referência na região norte do Brasil. Revista Ciência Agroambientais 13(2):19-31.

Silva AO, Silva EFF, Moura GBA, Lopes PMO (2012) Avaliação do desempenho de métodos de estimativa de evapotranspiração potencial para a região Norte de Recife-PE. Engenharia na Agricultura 20(2):163-174. doi: https://doi.org/10.13083/reveng.v20i2.291.

Silva MVT, Carneiro MA, Ferreira PPB, Conceição GC, Oliveira FL, Maracaja PB (2014) Comparação de métodos evapotranspiração de referência para cidade de Piracicaba-SP. ACSA - Agropecuária Científica no Semi - Árido 10(2):61-65. doi: http://dx.doi.org/10.30969/acsa.v10i2.541.

Silva VJ, Paula Carvalho H, Silva CR, Camargo R, Teodoro REF (2011) Desempenho de diferentes métodos de estimativa da evapotranspiração de referência diária em Uberlândia, MG. Bioscience Journal 27(1):95-101. 
Souza AP, Carvalho DF, Silva LBD, Almeida FT, Rocha HS (2011) Estimativas da evapotranspiração de referência em diferentes condições de nebulosidade. Pesquisa Agropecuária Brasileira 46:219-228.

Tagliaferre C, Silva R, Rocha F, Santos L (2010) Estudo Comparativo de diferentes metodologias para determinação da evapotranspiração de referência em Eunápolis - BA. Revista Caatinga 23(1):103-111.

Tanaka AA, Souza AP, Klar AE, Silva AC, Gomes AWA (2016) Evapotranspiração de referência estimada por modelos simplificados para o estado do
Mato Grosso. Pesquisa Agropecuária Brasileira 51(2):91-104. doi: 10.1590/S0100204X2016000200001.

Vallory ND, Dohler RE, Cecílio RA, Zanetti SS (2016) Métodos empíricos para estimativa da evapotranspiração de referência no estado do Rio de Janeiro. Revista Brasileira de Agricultura Irrigada 10(2):576 - 585. doi: 10.7127/rbai.v10n200407.

Willmott CJ (1981) On the validation of models. Physical Geography 2:184-194. 